\title{
PENGARUH PELATIHAN DAN PENGEMBANGAN DAN JABATAN FUNGSIONAL TERHADAP MOTIVASI BERPRESTASI DOSEN PERGURUAN TINGGI SWASTA
}

\section{(The Influence of Training and Functional Development on Achievement Motivation of Private Lecturer Higher Education)}

\author{
Effiyaldi $^{1}$ \\ ${ }^{1}$ Mahasiswa Program Doktor Manajemen, Universitas Persada Indonesia, Jakarta,
}

\begin{abstract}
The Low of lectures achievement motivation at the Private Higher Education (PTS) is the focus of this research. After implemented survey, it is found that $39.7 \%$ of training and development activities con-tributed to achievment motivation, whereas contibution of lecturer function is $34 \%$. According to statistical examination, lecturer functional has more significant influnced on achievment motivation. Hence,lecturer funtional development is one of the strategies to improve achievment motivation.
\end{abstract}

\begin{abstract}
ABSTRAK
Rendahnya motif berprestasi dosen Perguruan Tinggi Swasta (PTS) adalah fokus pada penelitian ini. Setelah dilakukan survei ditemukan bahwa 39,7\% kegiatan pelatihan dan pengembangan berkontribusi terhadap motif berprestasi, sedangkan jabatan fungsional berkontribusi $34 \%$. Pengujian statistik menunjukkan bahwa jabatan fungsional mempunyai pengaruh yang lebih signifikan dibanding dengan pelatihan dan pengembangan terhadap motif berprestasi. Dengan demikian, disarankan agar jabatan fungsional menjadi salah satu strategi untuk memperbaiki motif berprestasi.
\end{abstract}

Keywords. Training and development, functional positions, and achievment motivation.

Alamat Korespondensi:e-mail tanjab67@yahoo.co.id

\section{PENDAHULUAN}

Motivasi adalah suatu kondisi dalam diri seseorang dimana terjadi ketidak-seimbangan; akibatnya terdapat dorongan untuk berbuat sesuatu sehingga mengembalikan keadaan pada kedudukan yang seimbang (Handoko, 1992 dan Robert Word Worth dalam Sihombing, 2001). Salah satu teori motivasi yang banyak mendapat sambutan yang amat positif di bidang manajemen organisasi adalah Teori Hirarki Kebutuhan yang dikemukakan oleh Abraham Maslow. Menurut Maslow dalam Papu (2002), setiap individu memiliki kebutuhan-kebutuhan yang tersusun secara hirarki mulai dari tingkat yang paling mendasar sampai pada tingkat yang paling tinggi.

Orang yang termotivasi untuk berprestasi, memiliki tiga macam ciri umum dimana kinerja mereka timbul karena upaya-upaya mereka sendiri, dan bukan karena faktor-faktor sebagai berikut.Pertama, satu preferensi untuk mengerjakan tugas-tugas dengan derajat kesulitan moderat. Kedua, orang yang berprestasi tinggi juga menyukai situasi lain seperti misalnya kemujuran. Ketiga, mengidentifikasi mereka yang berprestasi tinggi adalah bahwa 
mereka menginginkan lebih banyak umpan balik tentang keberhasilan dan kegagalan mereka dibandingkan dengan mereka yang berprestasi rendah (Winardi, 2001dalamKusuma, 2004).

Berdasarkan data terkini, jumlah Perguruan Tinggi Swasta (PTS) dibawah binaan Kopertis Wilayah X di Kota Jambi sebanyak 26 buah. Untuk meningkatkan prestasi, DIKTI mengupayakan keikutsertaan dosen dalam program-program pendidikan dan latihan/pengembangan sebagai upaya meningkatkan kemampuan dosen,baik kemampuan akademik maupun kemampuan manajerial. Untuk memenuhi kekurangan jumlah dosen diupayakan melalui program peningkatan kualifikasi jenjang pendidikan dosen ke jenjang yang lebih tinggi, yaitu pendidikan di jenjang Pascasarjana.

Pengalaman di lapangan menunjukkan, belum banyak dosen yang memiliki jabatan fungsional dosen (terutama dosen-dosen Perguruan Tinggi Swasta non PNS). Hal ini disebabkan oleh semakin ketatnya aturan untuk memperoleh jabatan fungsional, ditambah lagi dengan aturan harus memiliki Nomor Induk Dosen Nasional (NIDN); sehingga berakibat pada rendahnya kinerja dosen. Kondisi seperti ini secara langsung atau tidak berdampak pada rendahnya aktivitas dosen dalam melaksanakan kegiatan penelitian dan pengabdian kepada masyarakat yang bermuara pada dikesampingkannya aktivitas untuk mengurus jabatan fungsional. Boleh jadi, kemudian kondisi ini akan memiliki kaitan signifikan dengan tidak tumbuhnya motivasi untuk meraih jabatan (Indrawan: 2003). Padahal perolehan jabatan fungsional berkontribusi terhadap kemajuan individu dosen yang bersangkutan dan institusi mereka. Sungguhpun demikian, perlu untuk dipahami bahwa jabatan fungsional adalah indikator profesionalisme seorang dosen. Lebih jauh dari itu, komposisi peraihan jabatan fungsional para dosen menjadi indikator mutu suatu perguruan tinggi di mata masyarakat (Indrawan, 2003).

Beberapa penelitian terdahulu yang mengulas tentang motivasi berprestasi antara lain; Jenny (2003) yang menghubungkan antara kepercayaan diri dengan motivasi berprestasi atlet bola basket Perbasi, Herlina (2003) yang menghubungkan iklim organisasi dengan motivasi berprestasi karyawan PT. Kemasindo Indah Triutama, Effiyaldi (2005) yang mengkaji pengaruh lingkungan kerja dan insentif terhadap motivasi kerja karyawan pada STIKOM Dinamika Bangsa Jambi, Effiyaldi dan Inge Handriani (2005) yang mengkaji pengaruh lingkungan kampus dan pelayanan terhadap motivasi belajar mahasiswa STIKOM Dinamika Bangsa. Pengembangan yang dilakukan terhadap penelitian ini adalah menambah variabel pendidikan dan pengembangan dan jabatan fungsional yang dikaitkan dengan motivasi berprestasi. Lingkup dalam penelitian ini adalah dosen-dosen Non Pegawai Negeri Sipil (PNS) pada Perguruan Tinggi Swasta (PTS) di Kota Jambi.

Berdasarkan fenomena tersebut, maka peneliti tertarik untuk melakukan penelitian dengan judul pengaruh pelatihan dan pengembangan dan jabatan fungsional terhadap motivasi berprestasi dosen perguruan tinggi swasta di Kota Jambi.

\subsection{Perumusan Masalah}

Berdasarkan uraian di atas, maka dapat dirumuskan masalah penelitian sebagai berikut:

1. Adakah pengaruh pelatihan dan pengembangan terhadap motivasi berprestasi dosen PTS di Kota Jambi ?

2. Adakah pengaruh jabatan fungsional dosen terhadap motivasi berprestasi dosen PTS di Kota Jambi?

3. Adakah pengaruh pelatihan dan pengembangan dan jabatan fungsional dosen secara bersama-sama terhadap motivasi berprestasi dosen PTS di Kota Jambi? 


\subsection{Tujuan Penelitian}

Tujuan diadakannya penelitian ini adalah;

1. Untuk mengetahui pengaruh pelatihan dan pengembangan dan jabatan fungsional dosen terhadap motivasi berprestasi dosen PTS di Kota Jambi.

2. Untuk mengetahui pengaruh pelatihan dan pengembangan terhadap motivasi berprestasi dosen PTS di Kota Jambi.

3. Untuk mengetahui pengaruh jabatan fungsional dosen terhadap motivasi berprestasi dosen PTS di Kota Jambi.

\section{TINJAUAN PUSTAKA}

\subsection{Pelatihan dan Pengembangan}

Pelatihan pada dasarnya merupakan kegiatan untuk memperbaiki kemampuan karyawan dengan cara meningkatkan pengetahuan dan keterampilan operasional dalam menjalankan suatu pekerjaan. Pelatihan adalah proses mengajarkan karyawan baru yang ada sekarang tentang keterampilan dasar yang mereka butuhkan untuk menjalankan pekerjaan (Dessler, 2009). Sedangkan pengembangan/pendidikan adalah suatu kegiatan untuk memperbaiki kemampuan karyawan dengan cara meningkatkan pengetahuan dan pengertian tentang pengetahuan umum dan pengetahuan ekonomi pada umumnya, termasuk peningkatan penguasaan teori pengambilan keputusan dalam menghadapi persoalan-persoalan perusahaan (Soeprihanto: 2001).Pada hakikatnya, pengertian pengembangan telah mencakup pengertian latihan sekaligus pengembangan/pendidikan yaitu usaha meningkatkan keterampilan maupun pengetahuan umum bagi karyawan. Secara umum, semakin tinggi suatu jabatan maka semakin penting faktor pengembangan/pendidikan sebagai syarat menduduki jabatan tersebut. Pelatihan bertujuan untuk memperbaiki penguasaan berbagai keterampilan dan teknik pelaksanaan kerja tertentu untuk kebutuhan sekarang, sedangkan pengembangan bertujuan untuk menyiapkan pegawainya agar siap memangku jabatan tertentu di masa yang akan datang.

Untuk melaksanakan program pelatihan dan pengembangan sebaiknya dilakukan analisis tentang kebutuhan, tujuan, sasaran serta isi dan prinsip terlebih dahulu agar pelaksanaan pelatihan tidak sia-sia. Menurut Barry (1994) dalam Umar (2003), pelatihan dapat terlaksana disebabkan oleh banyak hal, yaitu; perubahan staf, perubahan teknologi, perubahan pekerjaan, perubahan peraturan hukum, perkembangan ekonomi, pola baru pekerjaan, tekanan pasar, kebijakan sosial, aspirasi pegawai, variasi kinerja dan kesamaan dalam kesempatan. Selanjutnya, mengenai pelaksanaan pelatihan itu sendiri dapat dilaksanakan pada dua tempat, yaitu Pelatihan di tempat kerja (on the job training), dan pelatihan di luar tempat kerja (Umar, 2003).

\subsection{Jabatan Fungsional}

Di perguruan tinggi,untuk menyebut profesi dosen digunakan sebutan 'Jabatan Fungsional' atau ada juga yang menyebutnya dengan sebutan 'Jenjang Jabatan Akademis'. Terdapat beberapa tingkatan jabatan fungsional dosen yaitu; Asisten ahli, Lektor, Lektor Kepala dan Guru Besar(Hidayat, 2009). Jabatan Fungsional Dosen merupakan kedudukan yang menunjukkan tugas, tanggungjawab, wewenang dan hak seseorang Pegawai Negeri Sipil (dosen) dalam satuan organisasi yang dalam pelaksanaan tugasnya didasarkan pada keahlian 
dan atau keterampilan tertentu serta bersifat mandiri dan untuk kenaikan pangkatnya disyaratkan dengan angka kredit. Kenaikan Jabatan fungsional dosen pada hakikatnya merupakan kepercayaan atas kemampuan dosen, penghargaan atas prestasi akademik, pengakuan atas kemampuan akademik dan harapan dan peluang pengembangan jati diri kelimuan dan profesi dosen (Zuardi,2009).

Lebih lanjut Zuardi, 2009 menjelaskan, angka kredit yang disyaratkan untuk jabatan fungsional dosen meliputi pendidikan dan pengajaran minimal $40 \%$, penelitian minimal $10 \%$, pengabdian pada masyarakat maksimal 15\%, dan penunjang Tridharma Perguruan Tinggi maksimal 20\% dari jumlah angka kredit yang dibutuhkan setiap jenjang jabatan. Untuk setiap usul penilaian angka kredit penetapan/kenaikan jabatan fungsional dosen, dosen tersebut melakukan penilaian atas prestasi sendiri yang dituangkan dalam Daftar Usul Penilaian Angka Kredit (DUPAK). Selanjutnya berkas tersebut diusulkan ke Tim Penilai Angka Kredit Jurusan.

Kenaikan jabatan fungsional dosen dapat dilakukan sekurang-kurangnya satu tahun setelah menduduki jabatan fungsional terakhir, apabila yang bersangkutan telah memenuhi semua persyaratan kenaikan jabatan fungsional yang berlaku, sesuai dengan ketentuan pasal 9 ayat (6) Keputusan Menteri Koordinator Pengawasan Pembangunandan Aparatur Negara Nomor 38/KEP.MK.WASPAN/8/1999 tanggal 24 Agustus 1999 tentang jabatan fungsional dosen dan angka kreditnya.

\subsection{Motivasi Berprestasi}

Motivasi adalah kondisi internal yang spesifik dan mengarahkan perilaku seseorang ke suatu tujuan. (Lefton, 1982 dalam Alhadza, A., 2001). Achievement atau prestasi diartikan sebagai kesuksesan setelah didahului oleh suatu usaha. Prestasi merupakan dorongan untuk mengatasi kendala, melaksanakan kekuasaan, berjuang untuk melakukan sesuatu yang sulit sebaik dan secepat mungkin. (Lefton, 1982 dalamAlhadza, A., 2001).Menurut Crow dalam Sondix (2014) motivasi adalah suatu keadaan yang menyebabkan seseorang mampu melakukan dan mengarahkan sesuatu perbuatan atau aktivitas untuk mencapai tujuan tertentu.

McClelland menyimpulkan bahwa motivasi berprestasi adalah faktor penting yang menentukan tingkat pertumbuhan masyarakat. Ia menemukan tiga karakteristik umum dari orang yang memiliki motivasi berprestasi, yaitu: (1) kepiawaian menetapkan tujuan personal yang tinggi tetapi secara rasional dapat dicapai, (2) lebih komitmen terhadap kepuasan berprestasi secara personal dari dalam daripada iming-iming hadiah dari luar, dan (3) keinginan akan umpan balik dari pekerjaannya (McClelland, 1999 dalamAlhadza, A., 2001).Motivasi berprestasi adalah motif yang mendorong individu dalam mencapai sukses dan tujuan untuk berhasil dalam kompetisi dengan beberapa ukuran keberhasilan, yaitu dengan membandingkan perstasi (Crow dalam Sondix, 2014).

Selanjutnya, Maslow berpendapat bahwa perilaku manusia termotivasi ke arahself fulfillment. Setiap orang mempunyai motif bawaan yang selalu diperjuangkan untuk dipenuhi yang bergerak dari motif yang paling sederhana yaitu kebutuhan fisiologis sampai aktualisasi diri.Pada awalnya Maslow mengemukakan teorinya dengan hanya menyebutkan 5 hirarki kebutuhan manusia, namun kemudian ia menyempurnakan teorinya menjadi 7 hirarki kebutuhan manusia yaitu: 1) physiological needs, 2) safety needs, 3) belongingness and love needs, 4) esteem needs, 5) cognitive needs, 6) aesthetics needs dan 7) self actualization(Lefton, 1982 dalamAlhadza, A, 2001).

Herzberg mengembangkan model dua faktor. Dijelaskan bahwa ada dua faktor yang terpisah, yaitu higiene factor dan satisfier factor,yangmempengaruhi motivasi. Higiene 
factors adalah faktor yang apabila tidak ada dalam kondisi kerja akan menimbulkan rasa ketidakpuasan, namun keberadaannya hanya menimbulkan rasa netral. Satisfier factors adalah faktor yang keberadaannya sangat membangkitkan motivasi tetapi ketiadaannya jarang mengakibatkan rasa kecewa pada karyawan (Davis, 1990 dalamAlhadza, A., 2001).

Dari beberapa teori yang dikemukakan di atas, maka posisi motivasi berprestasi dapat diidentifikasi sebagai berikut.Pertama, pada teori Maslow, motivasi berprestasi dimulai dari hirarki ke 3 sampai aktualisasi diri. Aktualisasi diri merupakan puncak motivasi dan prestasi dari seseorang.Kedua, pada teori Herzberg, motivasi berprestasi berada pada faktor satisfier.Ketiga, pada teori Alderfer, motivasi berprestasi terkandung dalam kebutuhan berinteraksi dan kebutuhan untuk berkembang (Alhadza,A., 2001).

\section{METODOLOGI PENELITIAN}

\subsection{Populasi dan Sampel}

Dalam penelitian ini yang akan dijadikan sebagai populasi adalah seluruh dosen PTS dibawah pembinaan Kopertis Wilayah X yang berada di Kota Jambi. Sedangkan yang akan diambil sebagai sampel adalah sebanyak $20 \%$. Jumlah sampel sebesar ini didasarkan atas teori pengambilan sampel, bahwa untuk studi korelasional, dibutuhkan minimal 30 sampel untuk menguji ada tidaknya hubungan (Gay dan Diehl, 1996 dalam Kuncoro, 2003).

\subsection{Variabel Penelitian dan Pengukuran}

Penelitian ini terdiri atas 3 (tiga) variabel, yaitu; pelatihan dan pengembangan,Jabatan Fungsional serta Motivasi Berprestasi. Untuk mengukur ketiga variabel dalam penelitian ini digunakan skala Likertdengan memilih 5 (lima) alternatif jawaban yang disusun secara berjenjang dengan skala ordinal. Masing-masing variabel diukur dengan skala Ordinal yang menggunakan skala Likert dengan 5 opsi.

\section{HASIL PENELITIAN DAN PEMBAHASAN}

\subsection{Gambaran Umum}

Berdasarkan hasil olahan data primer diketahui bahwa variabel Pelatihan dan Pengembangan menunjukkan skor rata-rata sebesar 3,97619 lebih dari 3. Hal ini berarti responden mengapresiasi pertanyaan/pernyataan yang sesuai. Dari 6 pertanyaan yang diajukan, skor rata-rata tertinggi berada pada item pernyataan nomor 2 tentang "Kurikulum yang digunakan pada kegiatan pelatihan dan pengembangan yang pernah saya ikuti sudah sesuai dengan tujuan pelatihan tersebut", yaitu dengan skor 4,08571.Hal ini berarti ada kesesuaian antara kurikulum dengan tujuan pelatihan tersebut.Sedangkan rata-rata skor terendah berada pada item pernyataan nomor 3, tentang "Sarana yangtersedia/digunakan dalam kegiatan pelatihan yang pernah saya ikuti mendukung terselenggaranya kegiatan pelatihan dan pengembangan" sebesar 3,88571. Hal ini berarti ketersediaan sarana masih tergolong baik.

Selanjutnya nilai variabel Jabatan Fungsional diperoleh skor rata-rata sebesar 3,904. Skorrata-rata ini sudah lebih dari 3; ini berarti bahwa responden mengapresiasi pertanyaan/pernyataan yang diajukan melalui kuisioner dalam variabel ini. Dari 11 pernyataan yang diajukan, skor rata-rata tertinggi berada pada item pernyataan nomor 6 tentang "Jabatan 
fungsional dosen sangat berarti bagi dosen", yaitu dengan skor 4,428571. Artinya ada keberartian Jabatan fungsional dosen bagi dosen Perguruan Tinggi Swasta di Kota Jambi.Sedangkan rata-rata skor terendah berada pada item pernyataan nomor 10 tentang "Jabatan fungsional dosen merupakan suatu penghargaan bagi dosen yang memiliki, dibandingkan dengan dosen yang tidak memiliki jabatan fungsional dosen" sebesar 3,371429. Hal ini berarti bahwa penghargaanbagi dosen yang memilikiJabatan fungsional dosen masih tergolong baik.

Tentang motif berprestasi, diketahui bahwa hasil jawaban responden pada delapan indikator variabel motivasi berprestasimenunjukkan skor rata-rata sebesar 4,071429. Skorratarata ini sudah lebih dari 3; artinya bahwa responden mengapresiasipertanyaan/pernyataan yang diajukan melalui kuisioner dalam variabel ini. Dari 8 pernyataan yang diajukan, skor rata-rata tertinggi berada pada item pernyataan nomor 2, tentang "Kegiatan pelatihan yang diikuti dan jabatan fungsional dosen membuat dosen berorientasi pada kehidupan masa depan yang lebih", yaitu dengan skor 4,2857143. Hal ini berarti bahwa kegiatan pelatihan yang diikuti dan keberadaan jabatan fungsional dosen, membuat dosen Perguruan Tinggi Swasta di Kota Jambi berorientasi pada kehidupan masa depan yang lebih baik. Sedangkan rata-rata skor terendah berada pada item pernyataan nomor 4, tentang "Kegiatan pelatihan yang diikuti dan jabatan fungsional dosen lebih berorientasi pada tugas/sasaran" sebesar 3,8. Hal ini berarti bahwa kegiatan pelatihan yang diikuti dan keberadaan jabatan fungsional dosen mampu menjadikan dosen Perguruan Tinggi Swasta di Kota Jambi berorientasi pada tugas/sasarandalam melakukan pekerjaannya.

\subsection{Uji Validitas Dan Reliabilitas}

Berdasarkan output dari uji validitas dan uji reliabilitas terhadap instrumen Pelatihan Dan Pengembangan, diketahui bahwa seluruh item pertanyaan tersebut memiliki nilai $r$ hitung positif $(0,575 ; 0,725 ; 0,801 ; 0,630 ; 0,686 ; 0,774)$, nilai pada $r$ tabel adalah 0.2407 , nilaiR Cronbach's Alpha adalah 0,884, sedangkan $r$ tabel sebagaimana sudah dicari sebelumnya adalah 0,2407. Kesimpulannya, kuisioner tersebut valid dan reliable. Demikian juga untuk variabel Jabatan Fungsional, diperoleh nilai R hitung $(0,731 ; 0,585 ; 0,480 ; 0,810 ; 0,812$; $0,791 ; 0,825 ; 0,870 ; 0,808 ; 0,811)$. R Cronbach's Alpha bernilai 0,829, sedangkan $\mathrm{r}$ tabel seperti sudah dicari sebelumnya adalah 0,2407. Kesimpulan; kuisioner tersebut valid dan reliable. Selanjutnya untuk instrumen Motivasi Berprestasi, diperoleh nilai $\mathrm{R}$ hitung $(0,599$; $0,588 ; 0,391 ; 0,710 ; 0,464 ; 0,531 ; 0,384)$. R Cronbach's Alpha bernilai 0,815, sedangkan $\mathrm{r}$ tabel seperti sudah dicari sebelumnya adalah 0,2407. Kesimpulan; kuisioner tersebut valid dan reliable.

Hasil uji demikian menunjukkan bahwa proses statistik untuk proses perhitungan uji hipotesis dapat dilanjutkan.

\subsection{Pengaruh Pelatihan dan Pengembangan, dan Jabatan Fungsional}

Hasil perhitungan regressi pelatihan dan pengembangan dan jabatan fungsional terhadap motif berprestasi dapat dilihat pada Tabel 1 . 
Tabel 1.

Pengaruh Pelatihan Pengembangan, dan Jabatan Fungsional terhadap Berprestasi

\begin{tabular}{|c|c|c|c|c|c|}
\hline \multirow[b]{2}{*}{ Model } & \multicolumn{2}{|c|}{ Unstandardized Coefficients } & \multirow{2}{*}{$\frac{\text { Standardized Coefficients }}{\text { Beta }}$} & \multirow[b]{2}{*}{$\mathrm{t}$} & \multirow[b]{2}{*}{ Sig. } \\
\hline & $\mathrm{B}$ & Std. Error & & & \\
\hline 1 (Constant) & 5,521 & 8,116 & &, 680 &, 501 \\
\hline Latbang. $X_{1}$ & ,631 & ,301 &, 32 & 2,097 &, 044 \\
\hline Jafung. $X_{2}$ & 257 & 112 &, 35 & 2,302 & 028 \\
\hline
\end{tabular}

Sumber : Data diolah.

Dari Tabel 1. dapat disusun model persamaan regressi hasil penelitian sebagai berikut. Y $=5,521+0,631 \mathrm{X}_{1}+0,257 \mathrm{X}_{2}$, dimana $\mathrm{Y}$ motif berprestasi, $\mathrm{X}_{1}$ pelatihan dan pengembangan, dan $\mathrm{X}_{2}$ adalah jabatan fungsional. Dengan nilai alpha 5\%, maka semua koefisien $\mathrm{t}$ adalah signifikan. Artinya didapat alasan kuat untuk meyakini bahwa pelatihan pengembangan dan jabatan fungsional menentukan terhadap motif berprestasi. Sesuai dengan hipotesis penelitian, maka hipotesis penelitian dapat diterima.

Berkaitan dengan ini, diketahui pula bahwa $\mathrm{R}$ adalah 0,51 yang bermakna bahwa 51 persen dari perubahan motif berprestasi dapat dijelaskan oleh variabel pelatihan pengembangan dan jabatan fungsional. Penjelasan lanjut hal akan hal ini adalah sebagai berikut.

\section{- Pelatihan dan pengembangan}

Pelatihan dan pengembangan adalah hal yang intrinsik ditemui dalam karir seorang dosen. Sumberdaya yang digunakan untuk ini dapat berasal dari diri pribadi dosen maupun disediakan oleh kelembagaan. Dari hasil penelitian ini ditemui bahwa koefisien regressi adalah 0,631 sementara nilai korelasi adalah 0,384. Dari angka ini diyakini bahwa pelatihan dan pengembangan adalah hal yang menentukan terhadap motif berprestasi dosen. Hal ini didorong oleh motif yang datangnya dari dalam diri yang ingin berpretasi setelah pelatihan dilaksanakan.

\section{- Jabatan fungsional dan motif berpretasi}

Berdasarkan model regressi di atas diketahui bahwa koefisien motif berprestasi adalah 0,631, dimana nilai korelasinya adalah 0,41. Jabatan fungsional adalah jenjang kepegawaian khusus dosen dimana seorang staf memiliki hak dan kewajiban yang berbeda. Staf dengan jabatan fungsional tinggi mengalami proses sedemikian rupa sehingga dapat menunjukkan prestasi dalam bidang penelitian dan pengabdian. Artinya, dengan temuan ini beralasan untuk meyakini bahwa jabatan fungsional secaraparsial menentukan terhadap motif berpretasi.

Selanjutnya dapat ditentukan variabel yang berpengaruh lebih dominan. Dilihat dari tabel korelasi di atas, maka diketahuivariabel jabatan fungsional (X2) lebih berpengaruh terhadap motivasi berprestasi (Y). Namun korelasi yang terjadi baik antara variabel pelatihan dan pengembangan (X1) maupun jabatan fungsional (X2) terhadap variabel motivasi berprestasi (Y) adalah lemah, yaitu hanya sebesar 0,384 atau 38,4\% dan 0.410 atau $41 \%$ saja.

Jabatan fungsional lahir dari satu proses karir dosen yang bersamaan dengan aktifitas dalam kegiatan pendidikan dan pengajaran, penelitian, dan pengabdian. Secara unik, profesi dosen yang terdorong untuk meningkatkan ketiga kegiatan ini akan mengalami kenaikan jabatan yang lebih kontiniu. Semakin banyak kegiatan dimaksud, maka jabatan fungsionalnya 
akan cenderung semakin tinggi pula. Untuk itu, PT sebagai satu organisasi harus lebih fokus kepada upaya mendorong dosen termotivasi secara internal dalam hal berprestasi. Selanjutnya motivasi internal terdorong oleh berbagai reward yang diterima karena adanya kenaikan jabaan fungsional yang dialami seorang dosen.

\section{KESIMPULANDANSARAN}

\subsection{Kesimpulan}

Berdasarkan hasil penelitian di atas dapat disimpulkan bahwa kedua variabel bebas yang diteliti pengaruhnya signifikan terhadap motivasi berprestasi. Dan dari kedua variabel bebas tersebut pula, maka variabel jabatan fungsional yang mempunyai pengaruh lebih kuat terhadap motivasi berprestasi bagi dosen perguruan tinggi swasta di Kota Jambi.

\subsection{Saran}

Berikut beberapa saran yang dapat direkomendasikan dalam penelitian ini;

1. Harus ada upaya yang dilakukan agar terjadi perbaikan dan peningkatan motivasi berprestasi bagi dosen perguruan tinggi di Kota Jambi.

2. Karena variabel pelatihan dan pengembangan maupun variabel jabatan fungsional, pengaruhnya tidak signifikan terhadap motivasi berprestasi dosen perguruan tinggi di kota Jambi, maka perlu dikaji sebab-sebab tidak signifikannya pengaruh tersebut dan selanjtnya diadakan upaya peningkatan.

\section{Daftar Pustaka}

Alhadza, A.. 2001. Jurnal: Pengaruh Motivasi Berprestasi dan Perilaku Komunikasi Antarpribadi terhadap Efektivitas Kepemimpinan Kepala Sekolah(Survei Terhadap Kepala SLTP di Provinsi Sulawesi Tenggara).

http://www.depdiknas.go.id/Jurnal/40/Pengaruh\%20Motivasi\%20Berprestasi\%20dan\%2 OPerilaku.htm.

Dessler, Gary. 2009. Manajemen Sumber Daya Manusia. Jakarta : Index

Effiyaldi. 2005. Analisis Pengaruh Lingkungan Kerja Dan Insentif Terhadap Motivasi Kerja Karyawan Pada STIKOM Dinamika Bangsa. Jurnal Unbari.

Effiyaldi dan Handriani, Inge. 2005. Analisis Pengaruh Lingkungan Kampus Dan Pelayanan Terhadap Motivasi Belajar Mahasiswa Pada STIKOM Dinamika Bangsa. Jurnal Processor. Edisi 1 tahun 2005.

Hidayat, H. A. 2009. Artikel: Sosialisasi Penilaian Angka Kredit Dosen.

Herlina. 2003. Jurnal - Hubungan antara Iklim Organisasi Dengan Motivasi Berprestasi Pada Karyawan, PT. Kemasindo Indah Triutama. http://www.psikologi-untar.com.

Indrawan, Rully. 2003. Jurnal Online Kopertis IV ; Percik-Percik Pengalaman Mengurus Jabatan Fungsional.

Jenny. 2003. Hubungan Antara Kepercayaan Diri Dengan Peningkatan Motivasi Berprestasi; Suatu Studi Pada Atlet Bola Basket (Perbasi). http://www.psikologi-untar.com.

Keputusan Menteri Koordinator Pengawasan Pembangunandan Aparatur Negara Nomor 38/KEP.MK.WASPAN/8/1999 tanggal 24 Agustus 1999 tentang jabatan fungsional dosen dan angka kreditnya. 
Kuncoro, Mudrajad. 2003. Metode Riset Untuk Bisnis Dan Ekonomi. Bagaimana Meneliti dan Menulis Tesis. Erlangga. Jakarta.

Kusuma, ImmaHelianti. 2004. Studi Korelasional Antara Kecerdasan Adversity Dan Motivasi Berprestasi Dengan Kinerja Kepala Sekolah Di Lingkungan Yayasan BPK Penabur Jakarta. JurnalPendidikanPenabur-No.02/Th.III/Maret2004.

Papu, Johanes 2002.Memotivasi Karyawan, Kebutuhan Karyawan, Lingkungan Kerja Kondusif. Informasi Psikologi Online, e-psikologi.com.

Sihombing, Umberto. 2001. Jurnal Pengaruh Keterlibatan dalam Pengambilan Keputusan, Penilaian pada Lingkungan Kerja, danMotivasi Berprestasi Terhadap Kepuasan KerjaPamong Belajar. Portal Informasi Pendidikan Indonesia, Pusat Data dan Informasi Pendidikan, Balitbang - Depdiknas. www.depdiknas.go.id.

Sondix, 2014. Pengertian Motivasi dan Motivasi Berprestasi. http://sondix.blogspot.com/2013/08/pengertian-motivasi-dan-motivasi.html

Soeprihanto, Jhon. 2001. Penilaian Kinerja dan pengembangan Karyawan. BPFE Yogyakarta.

Umar, Husein, 2003. Riset Sumber Daya Manusia Dalam Organisasi. PT. Gramedia Pustaka Utama.

Zuardi, Trisno, 2009. Pedoman Penilaian Dan Pemberian Angka Kredit Jabatan Fungsional Dosen. Biro Kepegawaian Depdiknas RI. 